Zhou, K.; Barjenbuch, M.; Kabbe, C.; Inial, G.; Remy, C.

\title{
Phosphorus recovery from municipal and fertilizer wastewater: China's potential and perspective
}

Journal article | Accepted manuscript (Postprint)

This version is available at https://doi.org/10.14279/depositonce-8131

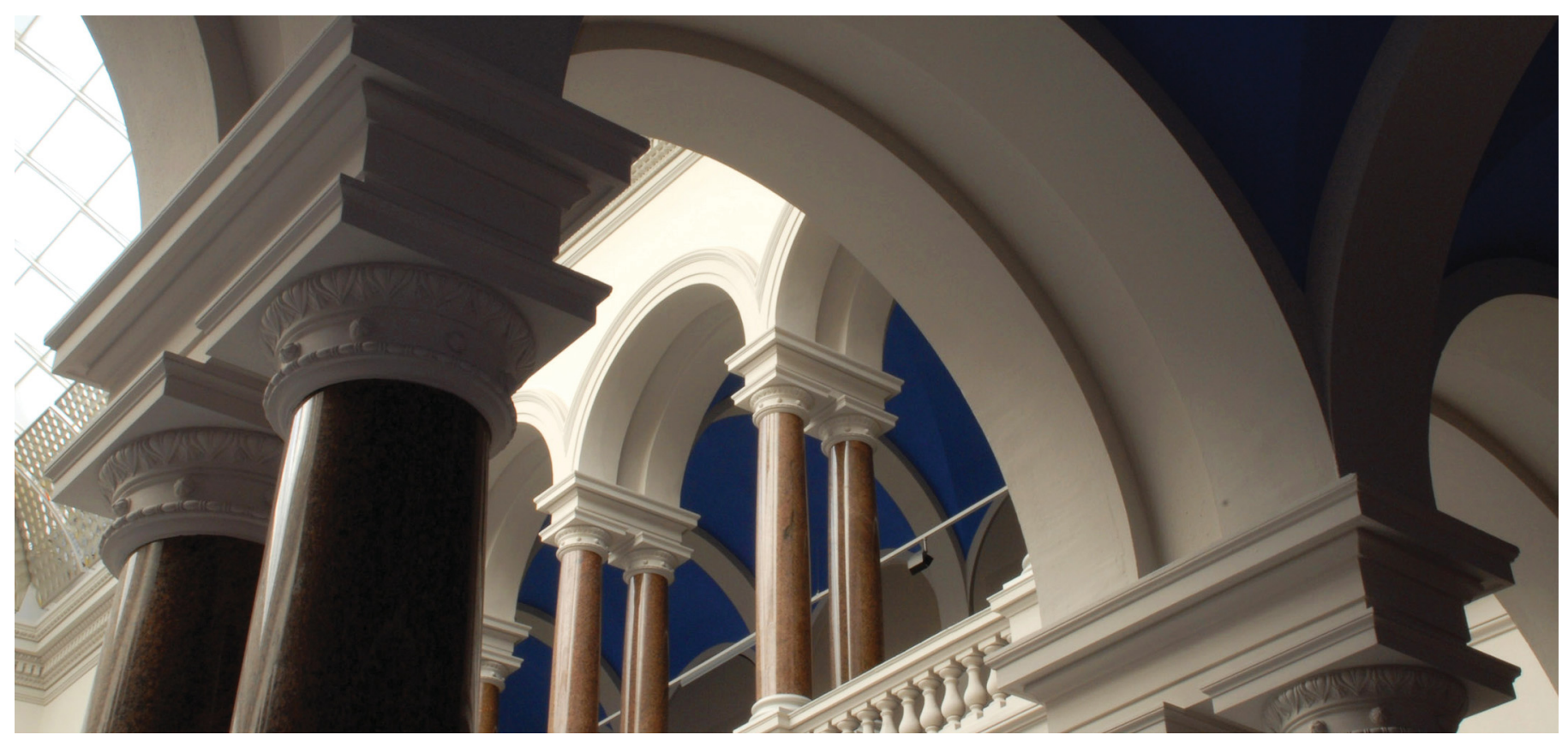

Zhou, K., Barjenbruch, M., Kabbe, C., Inial, G., \& Remy, C. (2017). Phosphorus recovery from municipal and fertilizer wastewater: China's potential and perspective. Journal of Environmental Sciences, 52, 151159. https://doi.org/10.1016/j.jes.2016.04.010 


\section{Phosphorus recovery from municipal and fertiliser wastewater: China's potential and perspective}

Kuangxin Zhou ${ }^{1,2, *}$, Matthias Barjenbruch ${ }^{2}$, Christian Kabbe ${ }^{1}$, Goulven Inial ${ }^{3}$, Christian Remy $^{1}$

${ }^{1}$ Berlin Centre of Competence for Water, Berlin, Germany

${ }^{2}$ Department of Urban Water Management, Technical University of Berlin, Berlin, Germany

${ }^{3}$ Research \& Innovation Asia, Veolia Environment, Beijing, China

* Corresponding author: Kuangxin Zhou

Mailing address: Berlin Centre of Competence for Water, Cicerostrasse 24, 10709 Berlin, Germany.

Tel.: +49(0)30-536 53-839;

Fax: +49(0)30-536 53-888;

E-mail: Kuangxin.zhou@kompetenz-wasser.de

\section{HIGHLIGHTS:}

- Review on current state of wastewater treatment plants and sludge treatment in China

- Assessment of discharged and recoverable P in Chinese wastewater

- A perspective on available technologies for $\mathrm{P}$ recovery according to specific conditions in China are presented

- Potentials and opportunities to recover and recycle phosphorus from wastewater were assessed

- Strategies and recommendations for future P-recovery in China 


\begin{abstract}
Phosphorus is a limited resource, which can neither be synthesized nor substituted in its essential functions as nutrient. Currently explored and economically feasible global reserves may be depleted within generations. China is the largest phosphate fertiliser producing and consuming country in the world. China's municipal wastewater contains up to $293,163 \mathrm{Mg} / \mathrm{a}$ of phosphorus $(\mathrm{P})$ which equals approximately $5.5 \%$ of the chemical fertiliser phosphorus consumed in China. Phosphorus in wastewater can be seen not only as a source of pollution to be reduced, but also as a limited resource to be recovered. Based upon existing P-recovery technologies and the current wastewater infrastructure in China, three options for phosphorus recovery from sewage sludge, sludge ash and the fertiliser industry according to the specific conditions in China were analysed.
\end{abstract}

\title{
KEYWORDS
}

Phosphorus recovery, Municipal Wastewater, Fertiliser Industry, Sewage sludge, China 


\section{INTRODUCTION}

Phosphorus is non-regenerable and non-replaceable limited resources (Asimov, 1959). Currently explored and economically feasible global reserves may be depleted within only a few generations (Childers et al., 2011). By 2050, the world's population is estimated to reach 9.1 billion; in order to feed the growing population, agricultural production would need to increase by 70 percent overall and nearly 100 percent in developing countries (FAO, 2009).

China is a big country with a large population and limited farmland area per capita with only 0.08 ha per capita compared with the world average of 0.2 ha per capita in 2012 according to the World Bank (WB, 2014). The production of sufficient food to feed the population is of vital importance for the country. In the year 2001, phosphorus was identified by the Ministry of Land and Resources of the People's Republic of China (MLR, 2012) as one of the most important 20 minerals which, after 2010, cannot meet the development needs of the national economy.

According to statistics from the United States Geological Survey (USGS, 2015), China's phosphorus reserves are 3.7 billion Megagram $(\mathrm{Mg}), 5.52 \%$ of the global total volume. Based on current phosphate rock mine production with 100 million Mg in 2014 (USGS, 2015), Chinese phosphorus ore may run out within 37 years. It is a remarkable fact that there is only little high-grade phosphorus ore, but the country is rich in low-grade phosphorus ore. More than $80 \%$ is low grade phosphate rock and the average grade only reaches $17 \%$ of phosphorus pentoxide $\left(\mathrm{P}_{2} \mathrm{O}_{5}\right)$ (Huang et al., 2014; Lu, 2004).

In Europe, phosphate rock is officially considered to be one of the 20 critical raw materials by the European Commission in 2014 (EC, 2014). The recovery of phosphorus has been repeatedly discussed due to the strong dependency above $90 \%$ on imports (De Ridder et al., 2012) and the food security of the growing population worldwide. Various phosphorus recovery technologies have been developed and tested in pilot or industrial scale. Among these technical options, phosphorus is mostly recovered by precipitation or crystallization processes in the form of HAP (hydroxyapatite, $\left.\mathrm{Ca}_{5}\left(\mathrm{PO}_{4}\right)_{3} \mathrm{OH}\right)$ or struvite $\left(\mathrm{MgNH}_{4} \mathrm{PO}_{4} \cdot 6 \mathrm{H}_{2} \mathrm{O}\right)$. The recovered products can be utilized as fertiliser in agricultural or specific industry.

Consequently, closure of the anthropogenic phosphorus cycle through recovery and recycling of phosphorus from municipal wastewater and sludge, as well as from special industry wastewater, may help to avoid eutrophication, promote resource conservation and increase the value chain efficiency of this precious resource.

\section{STATUS OF THE MUNICIPAL WASTEWATER INFRASTRUCTURE IN CHINA}




\subsection{The development of urban sewage treatment}

In 1984, the first large-scale wastewater treatment plant (WWTP), the Tianjin Jizhuangzi wastewater treatment plant was built and put into operation with a treatment capacity of 260,000 $\mathrm{m}^{3}$ (Fu et al., 2008). After 1990, with the rapid development of the economy, rapid urbanization and industrialization and the increasing environmental standards in China, the wastewater treatment infrastructure stepped into a rapid development period and improved the quantity of wastewater treatment facilities and also the effectiveness of treatment.

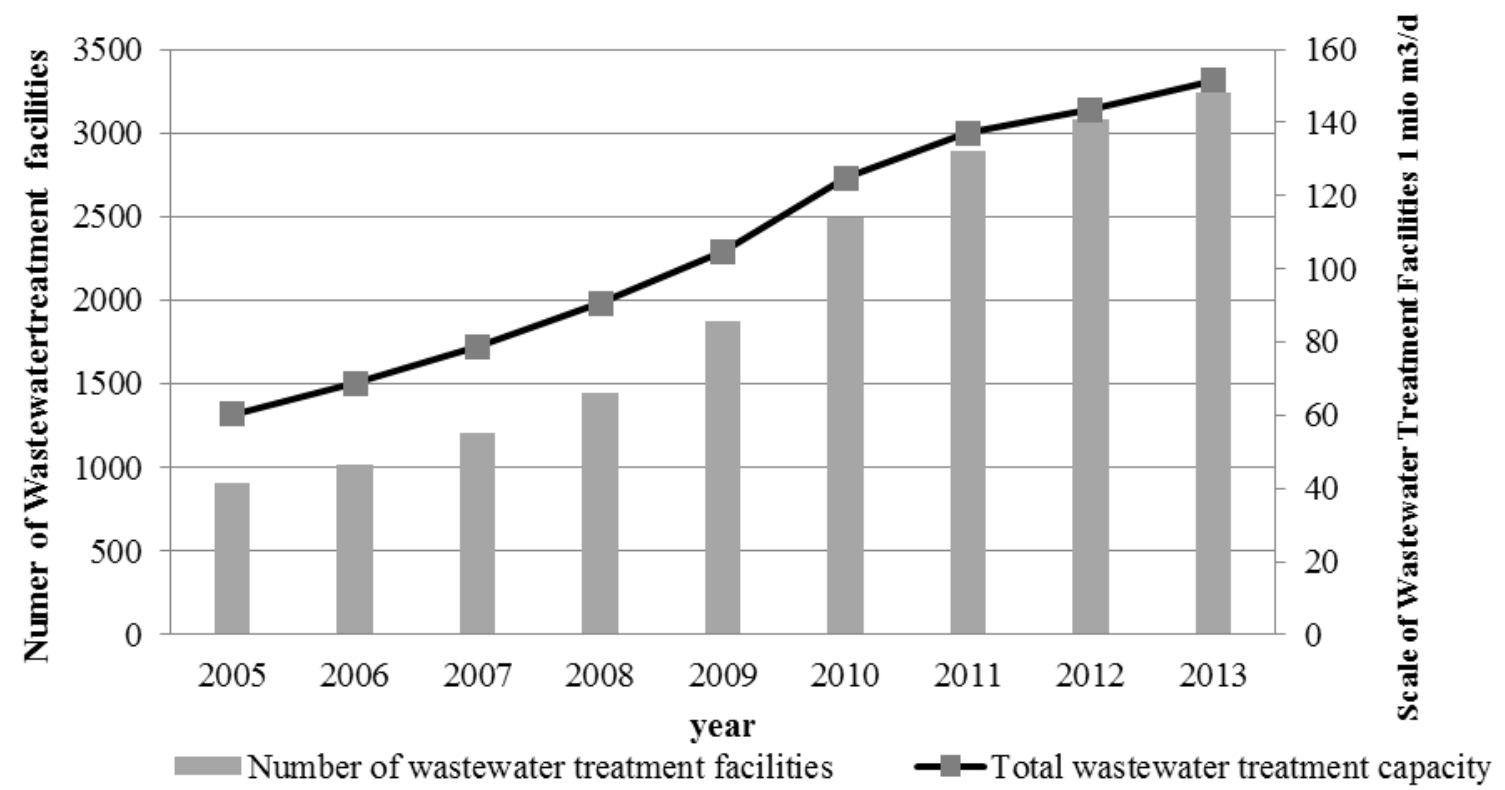

Figure 1: Development of urban sewage treatment from 2005 to 2013 in China (MOHURD, 2016)

Fig.1 shows the development of treatment capacity for urban sewage and the number of facilities from 2005 to 2013. During the past years, China's sewage treatment sector has experienced rapid development. In April 2015, the General Office of the State Council issued the "National Water Pollution Prevention and Treatment Action Plan of China" (MEP, 2015) to address nationwide water protection; the objective of municipal wastewater treatment is that by the end of 2020, the city and county municipal wastewater treatment rates should reach $95 \%$ and $85 \%$ respectively.

Although China's urban wastewater treatment industry has seen much progress in terms of scale and number since the 1990s, the conditions of the municipal water networks and the treatment rate in rural areas still needs to be improved. In 2013, the wastewater treatment rate of the cities, counties, towns and villages are respectively 89\%, 79\%, 19\%, 5\% (MOHURD, 2016). The majority of wastewater generated in rural areas undergoes limited or discharge to water bodies without treatment. According to the corresponding population distribution in 
different areas (MOHURD, 2016), 37\% of the population is connected to wastewater treatment systems in China.

\subsection{Wastewater Treatment Process}

There are three major steps in state-of-the-art wastewater treatment schemes, i.e. primary physical treatment, secondary biological treatment and tertiary treatment (Halling-Sørensen and Jorgensen, 1993). Most Sewage treatment plants in China are centralized with biological wastewater treatment.

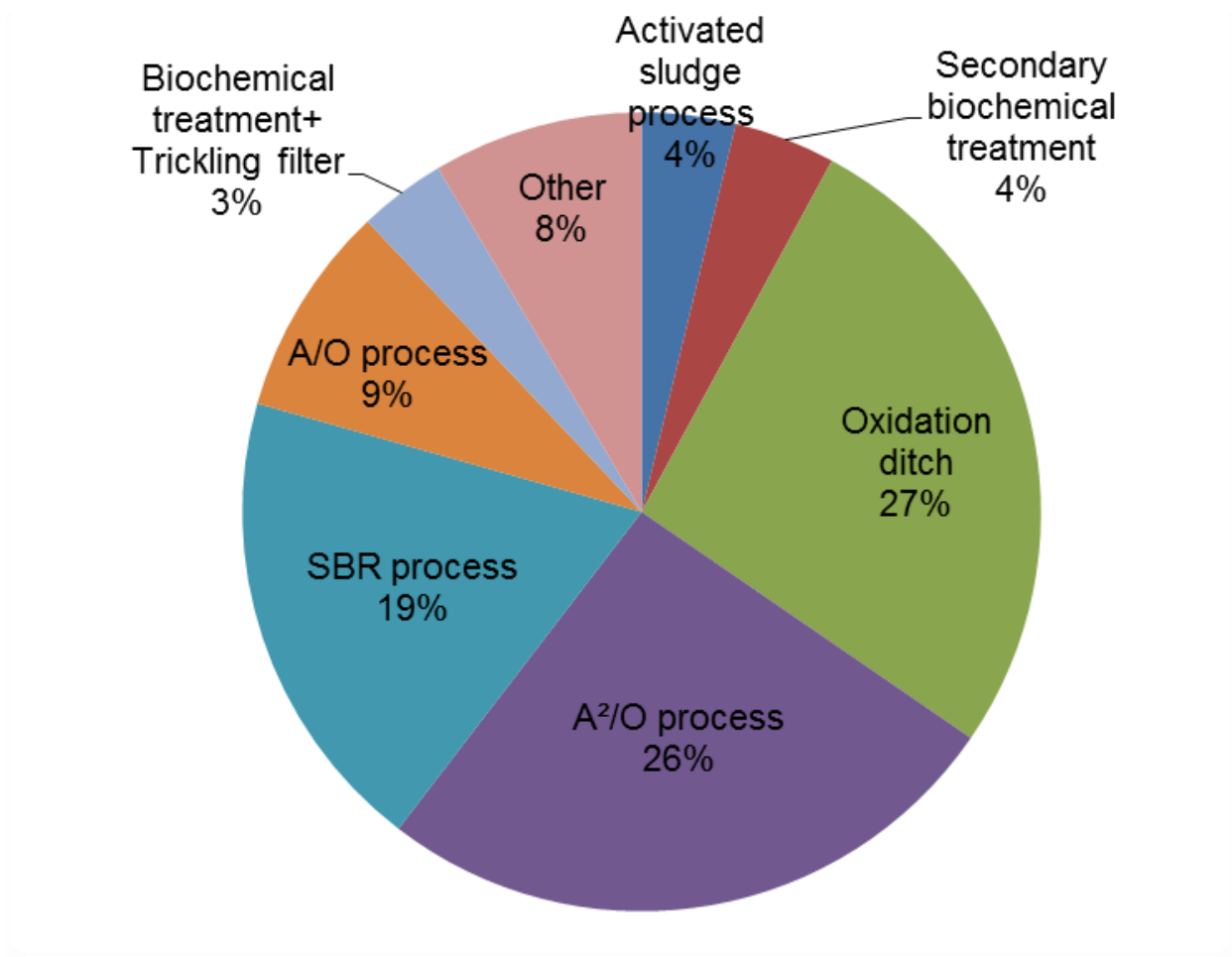

Figure 2: Variety of different processes of municipal WWTPs in China

Fig. 2 shows the variety and distribution of different processes of WWTP in China. According to the statistics of the Ministry of Environmental Protection of the People's Republic of China (MEP, 2014) for 4,136 commissioned wastewater treatment plants in 2013, the most widely used technologies are the Oxidation Ditch Process with a share of $27 \%$, the AnaerobicAnoxic-Oxic $\left(\mathrm{A}^{2} / \mathrm{O}\right)$ process with a share of $26 \%$ and the Sequencing Batch Reactor (SBR) process with a share of $19 \%$.

$3 \%$ of super-large-scale $\left(>30 \times 10^{4} \mathrm{~m}^{3} / \mathrm{d}\right)$ and $13 \%$ of large-scale $\left(10-30 \times 10^{4} \mathrm{~m}^{3} / \mathrm{d}\right)$ WWTPs, were generally built in large and medium-sized cities. Most of these plants apply the $\mathrm{A}^{2} / \mathrm{O}$ process. The ratio of medium-scale $\left(1-10 \times 10^{4} \mathrm{~m}^{3} / \mathrm{d}\right)$ WWTPs was $75 \%$. They were generally built in medium and small size cities and commonly apply the oxidation ditch and SBR processes (Jin et al., 2014). 


\subsection{Phosphorus removal in WWTPs}

Two methods are currently being used around the world to remove phosphorus in wastewater: biological and chemical phosphorus removal and combination of both. In China, influent $\mathrm{NH}_{4}-\mathrm{N}$ ranges from 40 to $55 \mathrm{mg} / \mathrm{L}$, and total phosphorus (TP) ranges from 4 to $9 \mathrm{mg} / \mathrm{L}$ (Jin et al., 2014). According to the "Discharge standard of pollutants for municipal wastewater treatment plant" (GB18918-2002), the primary A standard of total phosphorus concentration in WWTPs effluent built after 2005 should not exceed $0.5 \mathrm{mg} / \mathrm{L}$. It is quite difficult to meet this requirement with biological phosphorus removal alone (Qiu and Ding, 2002). A potential reason for the low efficiency of enhanced biological phosphorus removal (EBPR) is the competition for carbon sources between denitrification and phosphorus release in sludge under an anoxic condition with respect to the sludge retention time (SRT) demand, the nitrate inhibition of phosphate release, which is not easily resolved (Chen et al., 2011; Peng et al., 2010; Qiu and Ting, 2014).

\subsection{Sewage sludge treatment in China}

In China, thickening, conditioning and dewatering are the three most applied methods for sludge treatment (Yang et al., 2015). There is no accurate official data of sludge disposal in China, rather conflicting sources with different estimates. According to (Yang et al., 2015), more than $84 \%$ of sludge is disposed by improper dumping. Regarding proper disposal, the most commonly used method is sanitary landfill (13\%), followed by land application (2\%), incineration $(0.4 \%)$ and building materials $(0.2 \%)$. Data from (Wang et al., 2015) indicates that, the most widely used disposal route was landfilling with a ratio of $63 \%$, followed by compost and agricultural use with the ratio of $14 \%$, incineration with the ratio of $2 \%$. The disposal route for around 22\% of sludge was unknown. Many WWTPs in China did not report clearly the treatment and final disposal of their sludge (Jin et al., 2014). In general, the majority of sludge is often without stabilization or drying and disposed to sanitary landfill or dumping sites.

So far, anaerobic sludge digestion (AD) is not been widely used in China. Until 2010, only about 50 WWTPs adopted AD to stabilize sludge and some of them were not under stable operation or were even closed (Kong, 2012). The main problems for sludge digestion are the lack of an overall development plan on $\mathrm{AD}$, the technical design parameters of sludge digestion not matching the specific local condition. On the other side, the utilization and efficiency of sludge digestion in China is not being high due to the low production of gas and the lower economic benefit. The technical reasons are the high sand content and less volatile organic compounds with $30-50 \%$ in the sludge (Dai et al., 2014). According to the overall 
situation in China, thickening-anaerobic digestion-dewatering and following land application (Does not include agricultural use) can be considered as the main technical route of sludge treatment and disposal in the future. This route is favorable to large-scale and medium-scale WWTPs due to the limited land resources in the city and shortage in energy supply in economically developed regions (Yang et al., 2015).

\section{MATERIALS AND METHODS}

Phosphorus recovery and recycling options need to be ecologic, including social acceptance and economical and technical feasibility. Based on real operational data and samples from selected WWTPs in China and available technical solutions in the EU research and demonstration project P-REX (www.p-rex.eu), a systematic analysis of different options was conducted.

The total concentration of phosphorus and nitrogen in sludge water, supernatants and centrates and were determined by spectrophotometry according to respective Chinese standards (GB11893-89) and (HJ636-2012). Ammonia nitrogen was determined with titration according to (GB7478-87).

For the determination of iron (Fe) and aluminium ( $\mathrm{Al})$ in sludge and sludge ash, samples were digested with nitric acid/hydrochloric acid according to the ASTM D3974-09 and measured in accordance with US EPA 6010/ICP-OES and US EPA 6020/ICP-MS. For the determination of phosphorus, samples were digested with sulphuric acid according to the APHA 4500P B, H.

\section{POTENTIAL AND OPTIONS FOR PHOSPHORUS RECOVERY IN CHINA}

In the year 2013, there was a total of 45.1 billion $\mathrm{m}^{3}$ (MOHURD, 2016) of municipal wastewater treated in counties and cities. The total phosphorus concentration in the WWTP influents ranged from 4 to $9 \mathrm{mg} / \mathrm{L}$ (Jin et al., 2014). Based on the average value of $6.5 \mathrm{mg} / \mathrm{L}$, the phosphorus discharged to municipal wastewater in cities and counties added up to approximately 293,163 Mg in the year 2013. The quantity of this phosphorus in municipal wastewater in 2013 corresponds to $6 \%$ of the chemical fertiliser phosphorus (P) consumption of 5.3 teragram (Tg) (Li et al., 2015) in 2010 in China.

According to a statistical analysis of 98 WWTPs in China (Guo et al., 2009), the total P concentration in municipal sewage sludge varies significantly, from a low of $2.2 \mathrm{~g} / \mathrm{kg}$ of sludge dry matter to $51.3 \mathrm{~g} / \mathrm{kg}$ ( $\mathrm{Li}$ et al., 2003) with a mean value of $22.2 \pm 6.64 \mathrm{~g} / \mathrm{kg}$. The treatment plants with high $\mathrm{P}$ concentration in sludge are mostly located in phosphate mining areas or in highly developed areas, e.g. Yunnan or Hong Kong. With the dry sludge production of 7.55 million $\mathrm{Mg}$ in 2013 (MOHURD, 2016) and the content mean value for phosphorus, the total phosphorus that is contained in the current Chinese sewage sludge is 
estimated to be $167,634 \mathrm{Mg} / \mathrm{a}$, or in other words, $57 \%$ of the totally discharged phosphorus. This low rate of $\mathrm{P}$ in sludge might be due to the dilution in sanitary sewers by infiltration and inflow, which causes low phosphorus of influent as the average value of $6.5 \mathrm{mg} / \mathrm{L}$.

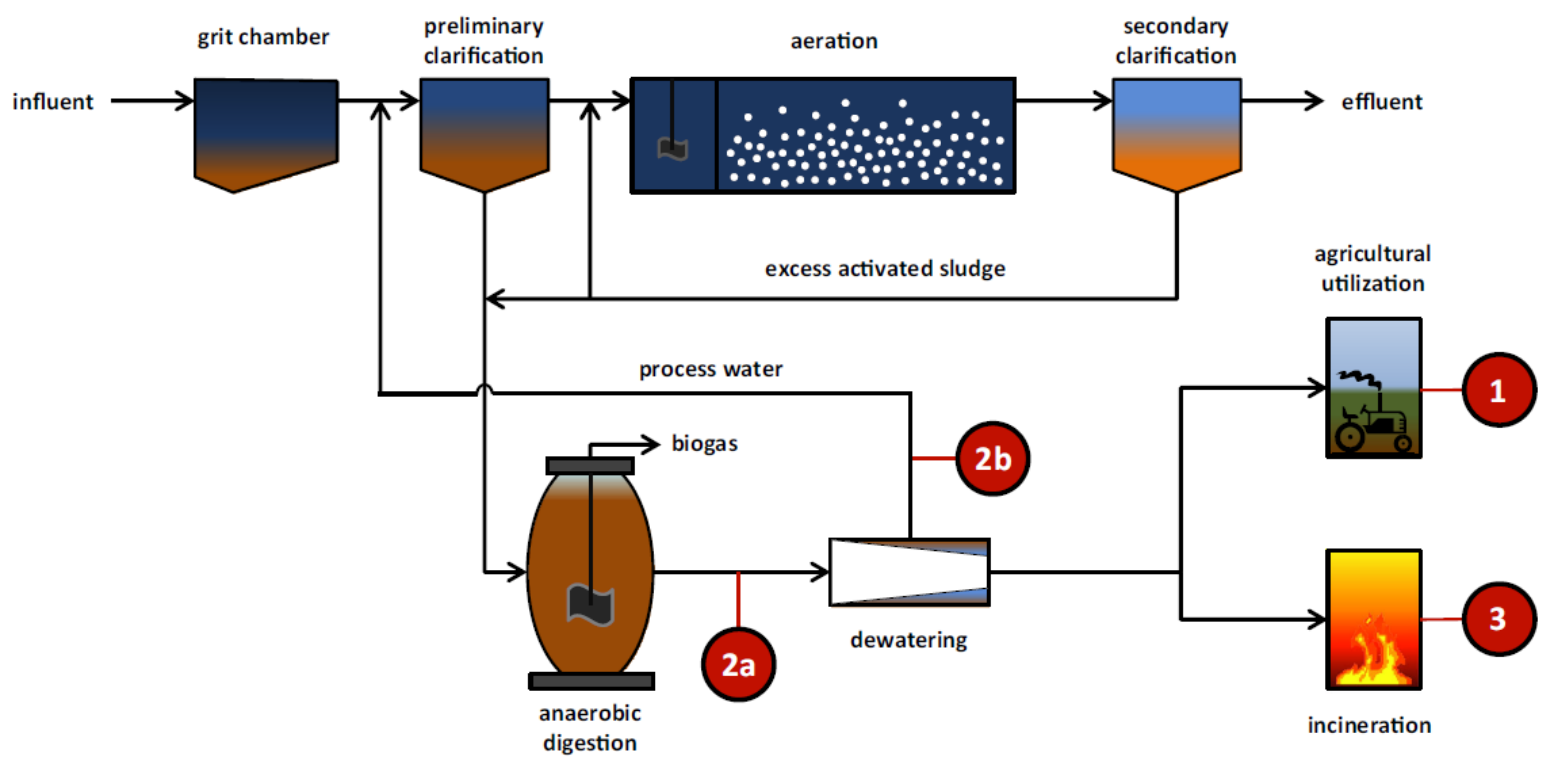

Figure 3 Hot spots for P recovery in WWTP (Kabbe and Remy, 2013). 1. Direct agricultural utilization of dewatered sludge; $2 a$. Undrained sludge after anaerobic digestion; $2 b$. Sludge liquor after dewatering; 3. From Ash after undiluted incineration

At a municipal wastewater treatment plant, phosphorus can be recovered and recycled mainly from three locations (Fig. 3). The first is direct land utilization of sewage sludge, the second includes the dissolved $\mathrm{P}$ in the aqueous sludge phase prior to dewatering and sludge liquor after dewatering and the third is the recovery from mono-incineration ash.

The maximum recovery potential from the aqueous phase and sludge phase without extraction are respectively $25 \%$ and $20 \%$ with regard to the WWTP influent (Kabbe, 2015). For the recovery by sludge leaching $(2 \mathrm{a}, 2 \mathrm{~b})$, a maximal $\mathrm{P}$ recovery rate of $70 \%$ can be achieved at high chemical and/or energy cost. Large amounts (70\% - 85\% of WWTP influent) of P can be recovered from mono-incineration ash (Egle et al., 2015; Niewersch et al., 2014). However, energy demand of ash treatment can vary depending on the process (ash leaching, thermochemical, metallurgic) and the potential integration of thermal processes into existing incineration facilities for efficient heat management (Remy, 2015).

$\mathrm{P}$ uptake from different $\mathrm{P}$ products of $\mathrm{P}$ recycling has been tested (Achat et al., 2014; Kataki et al., 2016; Römer, 2013; Wilken et al., 2015). Products from precipitation processes Mg compounds consistently showed a better $\mathrm{P}$ supply in relation to comparable Ca compounds. With struvite the same P uptake as triple super phosphate (TSP) was reached. 
The traditional land utilization of sewage sludge in agriculture is being considered as one of the most economical ways for sludge disposal, but the presence of toxic heavy metals, organic contaminants and pathogens in the sewage sludge greatly limits its direct use as a fertiliser. According to a study of heavy metals in sewage sludge over China (Guo et al., 2014), the concentration of $\mathrm{Cu}, \mathrm{Zn}, \mathrm{Cd}, \mathrm{Hg}$, and $\mathrm{Ni}$ in alkaline soils, about $2 \%, 6 \%, 6 \%, 3 \%, 4 \%$ of the samples exceeded the limits set by "Discharge standard of pollutants for municipal wastewater treatment plant" of China (GB18918-2002). In acid soils the non-attainment rate of $\mathrm{Cu}, \mathrm{Pb}, \mathrm{Zn}, \mathrm{Cd}, \mathrm{Hg}, \mathrm{Cr}$ and $\mathrm{Ni}$ were $7 \%, 1 \%, 10 \%, 27 \%, 20 \%, 2 \%$ and $12 \%$, respectively. The main sources of the heavy metals may be derived from high-density industrial zones, non-ferrous metal ores and anthropogenic activities(Guo et al., 2014). The source control of wastewater, especially the industry wastewater, can help decrease the amount of heavy metals entering the sewer and ensuring the quality of sludge.

Agricultural soils are also significantly influenced by $\mathrm{Cd}, \mathrm{Hg}$ and $\mathrm{Pb}$ derived from anthropogenic activities (Wei and Yang, 2010). The sewage sludge use on agricultural land is strictly limited. The amount, duration and quality of sludge applied to agriculture should meet the requirements of "Control standards for pollutants in sludges from agricultural use" (GB4284-84) and other existing relevant agricultural standards and regulations. Hence, costeffective alternative strategies and technologies for phosphorus recovery for agriculture are needed.

\section{RESULTS AND DISCUSSIONS}

\subsection{Option: Recovery in sludge}

Dissolved phosphorus is recovered directly from the digested sludge. In the AirPrex ${ }^{\circledR}$ process, the struvite is crystallized within the wet sludge and can, therefore, prevent down-stream struvite scaling and, at the same time, improve the sludge dewater ability by 3-6\% dry matter content and save the polymer costs for sludge dewatering (Heinzmann and Lengemann, 2014). Table 1: Anaerobic sludge digestion projects in China

\begin{tabular}{|l|l|l|l|c|l|}
\hline Name & $\begin{array}{l}\text { Wastewater } \\
\text { Treatment process }\end{array}$ & $\begin{array}{l}\text { Sludge } \\
\text { Treatment } \\
\text { capacity } \\
\text { (Mg DS/d) }\end{array}$ & Disposal & $\begin{array}{l}\text { year of } \\
\text { operation }\end{array}$ & Reference \\
\hline $\begin{array}{l}\text { Beijing } \\
\text { Gaobeidian }\end{array}$ & $\begin{array}{l}\text { active sludge treatment } \\
\text { process }\end{array}$ & 160 & - & 1999 & $($ Jiang, 2014) \\
\hline $\begin{array}{l}\text { Beijing } \\
\text { Xiaohongmen }\end{array}$ & $\begin{array}{l}\text { AAO process with biological } \\
\text { phosphorus removal }\end{array}$ & 160 & $\begin{array}{l}\text { land } \\
\text { application }\end{array}$ & 2009 & $\begin{array}{l}\text { Zhang et al., } \\
\text { Zhen } 2014)\end{array}$ \\
\hline $\begin{array}{l}\text { Chongqing } \\
\text { Jiguanshi }\end{array}$ & $\begin{array}{l}\text { reversed AAO process, } \\
\text { combined biological and } \\
\text { chemical phosphorus removal }\end{array}$ & 90 & $\begin{array}{l}\text { co- } \\
\text { incineration } \\
\text { and land } \\
\text { application }\end{array}$ & 2009 & (Zhang, 2009) \\
\hline
\end{tabular}




\begin{tabular}{|c|c|c|c|c|c|}
\hline Dalian Xiajiahe & $\begin{array}{l}\text { Constant Waterlevel SBR with } \\
\text { biological P-removal }\end{array}$ & 120 & $\begin{array}{l}\text { land } \\
\text { application }\end{array}$ & 2009 & $\begin{array}{l}\text { (Dai et al., } \\
\text { 2008; Yang et } \\
\text { al., 2015) }\end{array}$ \\
\hline $\begin{array}{l}\text { Haikou } \\
\text { Baishamen }\end{array}$ & $\begin{array}{l}\text { activated sludge and } \\
\text { biological aerated filter, } \\
\text { chemical phosphor removal }\end{array}$ & 100 & $\begin{array}{l}\text { agricultural } \\
\text { use }\end{array}$ & 2005 & $\begin{array}{l}\text { (Pan et al., } \\
\text { 2006; Sun et } \\
\text { al., 2008) }\end{array}$ \\
\hline $\begin{array}{l}\text { Qingdao } \\
\text { Maidao }\end{array}$ & $\begin{array}{l}\text { Enhanced clarification and } \\
\text { lamella settling with } \\
\text { biological aerated filter (BAF) }\end{array}$ & 21.8 & $\begin{array}{l}\text { land } \\
\text { application }\end{array}$ & 2008 & $\begin{array}{l}\text { (Wang et al., } \\
\text { 2012) }\end{array}$ \\
\hline $\begin{array}{l}\text { Shanghai } \\
\text { Bailonggang }\end{array}$ & $\begin{array}{l}\text { AAO process with chemically } \\
\text { enhanced primary treatment }\end{array}$ & 204 & $\begin{array}{l}\text { land } \\
\text { application }\end{array}$ & 2011 & $\begin{array}{l}\text { (Jiang et al., } \\
\text { 2013) }\end{array}$ \\
\hline $\begin{array}{l}\text { Wuhan } \\
\text { Sanjintan }\end{array}$ & $\begin{array}{l}\text { modified A/O process with } \\
\text { biological phosphorus removal }\end{array}$ & 40 & $\begin{array}{l}\text { land } \\
\text { application }\end{array}$ & 2013 & (Zhu, 2009) \\
\hline $\begin{array}{l}\text { Zhengzhou } \\
\text { Wangxin } \\
\end{array}$ & $\begin{array}{l}\text { AAO process with biological } \\
\text { phosphorus removal }\end{array}$ & 66 & - & 2009 & $\begin{array}{l}\text { (Li et al., } \\
\text { 2007) }\end{array}$ \\
\hline $\begin{array}{l}\text { Tianjing } \\
\text { Jizhuangzi } \\
\text { (Tianjing } \\
\text { Jinnan sludge } \\
\text { treatment plant) }\end{array}$ & $\begin{array}{l}\text { AAO process with deep bed } \\
\text { filtration, combined biological } \\
\text { and chemical P-removal }\end{array}$ & 160 & $\begin{array}{l}\text { land } \\
\text { application }\end{array}$ & 2015 & $\begin{array}{l}\text { (NCME, } \\
\text { 2013) }\end{array}$ \\
\hline
\end{tabular}

In table 1 selected sewage sludge digestion projects in China are listed. These WWTPs are mostly operated with combined biological and chemical phosphorus removal. Among them, several plants have reported that struvite precipitation has been an problematic issue, e.g. Shanghai Bailonggang (Jiang et al., 2013), Haikou Baishamen (Pan et al., 2006). For most of these plants with anaerobic digestion, land application is the first choice for sewage disposal. This option is designed for a significantly more efficient for WWTPs with biological Phosphorus elimination (Bio-P) and sludge digestion. For the phosphorus that is fixed within the sludge, after chemical precipitation with ferrous or ferric, aluminum, direct struvite crystallization is not a suitable option for recovery. Hence, with the current sewage and wastewater treatment facilities in China, only a few WWTPs are adapted to this option, such as Dalian Xiajiahe, Wuhan Sanjintan Beijing Xiaohongmen WWTP etc. The current limits of this option for the WWTPs in China are the shortage of combined biological phosphorus removal and anaerobic sludge digestion.

\subsection{Option: Recovery from sludge water}

Phosphorus is recovered from the supernatants of the digested sludge after liquid-solid separation. In the Struvia ${ }^{\mathrm{TM}}$, Pearl ${ }^{\circledR}$, and Airprex ${ }^{\circledR}$ process, an important component of these technologies are crystallization reactors. In these processes, struvite is precipitated by dosing $\mathrm{MgCl}_{2}$ and increasing the $\mathrm{pH}$ by adding caustic soda $(\mathrm{NaOH})$ or aeration. 
Table 2: Parameters of sludge water in WWTP A in China (mean value) ${ }^{\mathrm{a}}$

\begin{tabular}{lllllll}
\hline & Influent & Effluent & $\begin{array}{l}\text { Supernatant } \\
\text { Pre- } \\
\text { thickener } \\
\text { before } \\
\text { digester }\end{array}$ & $\begin{array}{l}\text { Supernatant } \\
\text { Post- } \\
\text { thickener } \\
\text { after digester }\end{array}$ & $\begin{array}{l}\text { Centrate } \\
\text { after } \\
\text { dewatering }\end{array}$ & $\begin{array}{l}\text { Total } \\
\text { returns }\end{array}$ \\
& mg/l & $\mathrm{mg} / \mathrm{l}$ & $\mathrm{mg} / \mathrm{l}$ & $\mathrm{mg} / \mathrm{l}$ & $\mathrm{mg} / \mathrm{l}$ & $\mathrm{mg} / \mathrm{l}$ \\
\hline $\begin{array}{l}\text { Total } \\
\text { nitrogen } \\
\text { (TN) }\end{array}$ & 23.9 & 19.8 & 391 & 614 & 533 & 320 \\
$\begin{array}{l}\text { NH4 }-\mathbf{N} \\
\text { Total }\end{array}$ & 19.0 & 15.6 & 325 & 489 & 398 & 249 \\
Phosphorus & 3.5 & 2.0 & 205 & 289 & 238 & 180 \\
\hline
\end{tabular}

${ }^{a}$ The sludge water samples were taken from WWTP A in China from January to May 2014. The influent and effluent of the WWTP were analysed every two days. Other supernatants and centrates were analysed every second week.

Municipal wastewater treatment plant A in south China has a capacity of $300,000 \mathrm{~m} / \mathrm{d}$, and the wastewater is treated with activated sludge process and before discharge to the deep sea. After digestion, phosphate is released into the liquid phase, in which total phosphorus increases from $205 \mathrm{mg} / \mathrm{L}$ to $289 \mathrm{mg} / \mathrm{L}$ (Table 2). Under specific conditions, this phosphate reacts with magnesium and ammonium and buildup struvite in pipes and dewatering facilities, which needs to be cleaned every one or two weeks by high pressure water in this plant. The replacement of pipelines with external mechanical cleaning is also used to cope with the scaling problem in another WWTP in the east coast of China. The mechanical treatment is preferred due to economic reasons, i.e. the low cost of manpower, compared to the chemical treatment by anti crustration agents. In the Tianjing Chennan sludge treatment plant, a new project with recovery of phosphate from sludge water with AirPrex ${ }^{\circledR}$ process is under construction.

Regarding the high soluble phosphorus and ammonia concentration in centrates in such plants in China, techniques are available, to recover $80-90 \%$ of the dissolved phosphorus (Niewersch et al., 2014) in sludge water. The limits of this option are no more than $20 \%$ of a WWTP's Phosphorus load can be recovered, and this only if enhanced biological P removal is applied, and its economic viability should be considered. 


\subsection{Option: Recovery from sludge water with sludge extraction}

Phosphorus is recovered from the supernatant of the digested sludge after acidic leaching or thermal hydrolysis pre-treatment and followed by liquid-solid separation e.g. the Gifhorn, Stuttgart and Budenheim process.

Due to the additional increase of phosphorus dissolved in the sludge supernatant by acidic treatment, the processes with sludge extraction step are applicable for digested sludge from WWTPs with both EBPR and chemical P elimination. Hence, with the current sewage and wastewater treatment facilities in China, Shanghai Bailonggang, Haikou Baishamen and Tianjing Jinnan WWTP, among others, are technically suitable for this option. However, it was shown that with the current reagent strategies and investment costs, the struvite recovery process was not economically feasible for WWTPs with AD and P-physicochemical removal, only in the case of Bio-P removal WWTPs with AD (Garcia-Belinchón et al., 2013).

\subsection{Option: Phosphorus recovery from sewage sludge ash}

The P recovery from sewage sludge ash (SSA) is generally divided into two approaches: the wet-chemical (LeachPhos) and thermal processes (AshDec). Wet-chemical approaches consist of an acidic or alkaline digestion of SSA followed by a separation of P from dissolved (heavy) metals and organics. In Germany, 54.7\% (Wiechmann et al., 2015) of the sludge is incinerated, and only about $3.45 \%$ (Fang et al., 2012) of sludge in China is treated by incineration. The quantity of recoverable phosphorus in sludge ash in China is not calculable due to the lack of reliable mono-incineration data.

Table 3: Analysis of selected parameters of composite sludge feed to incinerator and sludge ash in the Sludge Treatment Facility in Hong Kong, China ${ }^{\text {a }}$

\begin{tabular}{|l|l|l|l|l|l|l|l|l|}
\hline & \multicolumn{9}{|l|}{ Sludge } & \multicolumn{2}{l|}{ Sludge Ash } \\
& $\begin{array}{l}\text { \% Moisture } \\
\text { Content (dried } \\
\left.@ 103^{\circ} \mathrm{C}\right)\end{array}$ & $\begin{array}{l}\text { \% P } \\
\text { Dry } \\
\text { Matter }\end{array}$ & $\% \mathrm{Al}$ & \% Fe & $\begin{array}{l}\text { Moisture } \\
\text { Content (dried } \\
\left.@ 103^{\circ}\right)\end{array}$ & $\begin{array}{l}\% \mathrm{P} \\
\text { Dry } \\
\text { Matter }\end{array}$ & $\begin{array}{l}\% \\
\mathrm{Al}\end{array}$ & $\begin{array}{l}\% \\
\mathrm{Fe}\end{array}$ \\
\hline $\begin{array}{l}\text { Test on } \\
\text { December } \\
\text { 4th, 2014 }\end{array}$ & 69.3 & 0.925 & 0.577 & 3.1 & 0.1 & 2.74 & 2.74 & 10.9 \\
\hline $\begin{array}{l}\text { Test on on } \\
\text { January 2nd, } \\
\text { 2015 }\end{array}$ & 67.2 & 1.12 & 0.78 & 2.85 & 2.1 & 5.25 & 3.8 & 12.7 \\
\hline Mean & 68.25 & 1.023 & 0.679 & 2.975 & 1.1 & 3.995 & 3.27 & 11.8 \\
\hline
\end{tabular}

${ }^{a}$ The tested sludge and sludge ash samples were taken from incineration Sludge Treatment Facility in Hong Kong from December 2014 to January 2015.

The Sludge Treatment Facility (STF) in Hong Kong is the world's largest sludge incineration facility with a capacity of $600 \mathrm{Mg}$ of dry sludge per day. The facility adopts fluidized bed 
incineration technology to decompose sewage sludge at $850^{\circ} \mathrm{C}$. In Table 3 , the selected parameters of composite sludge feed to incinerator and sludge ash are presented.

SSA in the STF of Hong Kong contains a phosphorus (P) concentration of around 4\%, which, compared to the mean phosphorus content in Germany of $8.9 \%$ (Krüger and Adam, 2015) is only half of the content as in Germany. The concentrations of aluminum (Al) $3.3 \%$ and iron (Fe) $11.8 \%$ in Hongkong are similar to the mean value in Germany, 5.2\% and $9.9 \%$ respectively (Krüger and Adam, 2014). For elementary white phosphorus $\mathrm{P}_{4}$ production with the Thermphos process the molar ratio of Fe/P reaches about 0.6 in Hong Kong, which exceed the limit value of 0.2 (Petzet and Cornel, 2009). The high iron concentration in SSA increases the energy demand and reduces the output of $\mathrm{P}_{4}$. Although with the current available technology approximately $2000 \mathrm{t}$ P/a can be recovered in this plant, the relatively low phosphorus concentration should be considered to ensure the economic viability. The limitation of this option in China is the low $\mathrm{P}$ concentration in sludge ash compared to Europe.

\section{PHOSPHATE FERTILISER INDUSTRY}

Various industries produce wastewater that contains a high concentration of phosphorus. This includes fertiliser, semiconductor, phosphoric acid processing and swine wastewater (Hao et al., 2011). The mentioned processes (Struvia ${ }^{\mathrm{TM}}$, Crystallactor, Pearl ${ }^{\circledR}$, AirPrex ${ }^{\circledR}$ etc.) for sludge water are also applicable to industrial wastewater containing a significant concentration of dissolved ortho-phosphate.

China is not only the largest phosphorus consumer but also the largest producer. There were 1,118 phosphate fertiliser enterprises in China in 2005 (Zhang et al., 2009), and in the plants, a significant amount of wastewater containing phosphate and fluoride is generated. The use of lime as a precipitating agent for fluoride and phosphate can be considered as the most common technique for wastewater from phosphate fertiliser plants (Grzmil and Wronkowski, 2006). But the large amount of phosphorus in the wastewater cannot be directly recycled in agriculture due to the low plant availability of fluorapatite (Manahan, 1997; Ndala et al., 2010). A controlled phosphorus recovery with separate precipitation of fluorides and phosphates in a two-stage process would be an adapted option. It was found that, by acting on precipitation $\mathrm{pH}$ ranging from 2.6 to 3.7 , a "selective" removal of 97-98\% fluoride from phosphoric acid/hydrofluoric acid mixture was possible while that of phosphate did not exceed 6-8\% (Gouider et al., 2009). It can also be observed that, using calcium, fluorides were mainly separated $(\mathrm{pH} 3)$ in the first stage, and phosphates $(\mathrm{pH} \mathrm{8)}$ were mainly separated in the second stage amounted to ca. $85-88 \%$ and ca. $63-73 \%$, respectively. (Grzmil and Wronkowski, 2006). 
Table 4: Different streams and compositions of wastewater in a fertiliser plant in China ${ }^{\mathrm{a}}$

\begin{tabular}{|l|l|l|l|l|l|l|l|l|}
\hline & $\begin{array}{l}\text { Wastewater } \\
\text { flows } \\
\left(\mathrm{m}^{3} / \mathrm{h}\right)\end{array}$ & $\begin{array}{l}\mathrm{COD} \\
(\mathrm{mg} / \mathrm{L})\end{array}$ & $\begin{array}{l}\mathrm{NH}_{4}-\mathrm{N} \\
(\mathrm{mg} / \mathrm{L})\end{array}$ & $\begin{array}{l}\mathrm{F}^{-} \\
(\mathrm{mg} / \mathrm{L})\end{array}$ & $\begin{array}{l}\mathrm{TP} \\
(\mathrm{mg} / \mathrm{L})\end{array}$ & $\begin{array}{l}\mathrm{SS} \\
(\mathrm{mg} / \mathrm{L})\end{array}$ & $\mathrm{pH}$ & $\begin{array}{l}\mathrm{TN} \\
(\mathrm{mg} / \mathrm{L})\end{array}$ \\
\hline $\begin{array}{l}\text { Ammonia } \\
\text { Wastewater }\end{array}$ & 200 & 300 & 300 & $/$ & $/$ & 200 & 8 & 300 \\
\hline $\begin{array}{l}\text { Phosphate } \\
\text { fertiliser } \\
\text { Wastewater }\end{array}$ & 200 & $/$ & 50 & 80 & 240 & 100 & 5 & 50 \\
\hline
\end{tabular}

${ }^{a}$ Data came from the operator of wastewater treatment plant

Table 4 shows the different streams and compositions of wastewater in a big fertiliser plant in the East China. The WWTP has two major types of wastewater: respectively ammonia wastewater with $300 \mathrm{mg} / \mathrm{L}$ ammonia-nitrogen from synthetic ammonia production and phosphorus-containing wastewater with $240 \mathrm{mg} / \mathrm{L}$ total phosphorus from phosphate fertiliser production. The high concentration of both components in the wastewater provides a good possibility for producing magnesium ammonium phosphate. The excess ammonium in the wastewater, with a molar ratio $(\mathrm{N}: \mathrm{P})$ of more than 1 , is also beneficial for struvite precipitation (Warmadewanthi and Liu 2009). For struvite formation in this fertiliser wastewater plant, an additional magnesium source is needed. A high calcium content in wastewater resulted in more calcium compounds rather than struvite in the precipitations (Hao et al., 2008). In this wastewater treatment plant approximately $1,800 \mathrm{t}$ of struvite can be recovered annually by the technology currently available, and the product can be sold directly to customers. Unlike in Europe, China is abundant in phosphate fertiliser plants, which produce a large amount of wastewater with a high concentration of phosphate and ammonia. Wastewater treatment with $\mathrm{P}$ recovery can provide a promising prospect for future $\mathrm{P}$ recovery in an ecological and economically efficient way.

\section{SUMMARY AND PERSPECTIVE}

Growing urbanization in China caused a rising trend in domestic wastewater and sewage sludge discharges. The contained phosphorus is not yet recycled and ends up in water bodies or landfills.

An analysis of the potentials and limitations of existing P recovery technologies, taking into account their applicability to different types of WWTPs in China, shows that a huge amount of phosphorus is transferred to wastewater and sludge. However, some limitations should be taken into consideration, e.g. the existing WWTP infrastructure and sludge disposal routes. 
From a long-term perspective, anaerobic digestion followed by land application can be considered as the main technical route of sludge disposal for large-scale and medium-scale WWTPs. In this way, a large part of the phosphorus will be recycled in lands, gardens or parks in China. However, the quality of biosolids for land application should be strictly controlled. On sloping land there is the risk of runoff reaching watercourses and causing water pollution. It is in this sense that a clean sludge also gives cleaner water.

For the WWTPs with struvite incrustations the P recovery from sludge can be seen as the best option to solve this problem, instead of frequent mechanical cleaning. In most cases of recovery from sludge water, dissolution of $\mathrm{P}$ from solid sludge into the aqueous phase is needed. As special cases, sludge with an extremely high concentration of phosphorus potentially provides positive economics for the recovery of phosphorus, e.g. as in Yunnan and Hong Kong.

The average concentration of phosphorus in SSA in China is lower than that in Germany due to the high sand content in sludge and a lack of separation of rain water and municipal sewage. Therefore, the ash option is limited due to the low rate of mono-incineration and the low $\mathrm{P}$ concentration in SSA.

Therefore, the following suggestions for the future P recovery in China are:

- Increase wastewater collection and improve the phosphorus removal

- Promotion of sludge digestion and Bio-P and withdrawal from precipitation with iron salts

- A development strategy for a long-term perspective in sustainable P-recovery

- A legal framework governing recycling and the market for fertilisers

- Development of business models of companies utilizing P streams from wastewater

- Encouragement of research and promotion of a new treatment technology for P rich wastewater

\section{Conclusion}

There is no doubt that phosphorus is a finite resource. Although there is no "one-fits-all" option for phosphorus recovery and most of the $\mathrm{P}$ recovery technical options for municipal WWTPs face strong limitations in China, more efforts should be taken to increase both energy and resource efficiency. The recovery from industrial wastewater with a high concentration of phosphorus shows a higher potential than in municipal WWTPs due to easier market access and benefits to its operators. With an expected increasing percentage of municipal sewage sludge digestion and biological phosphorus removal, $\mathrm{P}$ recovery as struvite and recycling as fertiliser is recommended as one of the favorable options for $\mathrm{P}$ recycling. 


\section{Acknowledgement}

This study is funded under the Chinese Government Graduate Student Overseas Study Program by the China Scholarship Council (CSC). We thank Matthias Barjenbruch and Christian Kabbe, for the patient guidance, encouragement and advice. We thank also the colleagues from Berlin Centre of Competence for Water, Veolia China, Veolia France, who provided insight and expertise that greatly assisted the research. 


\section{References}

Achat, D. L., Sperandio, M., Daumer, M.-L., Santellani, A.-C., Prud'Homme, L., Akhtar, M., Morel, C., 2014. Plant-availability of phosphorus recycled from pig manures and dairy effluents as assessed by isotopic labeling techniques. Geoderma 232:24-33.

Asimov, I., 1959. Life's bottleneck. The Magazine of Fantasy and Science Fiction:31-40.

Chen, Y., 2013. Key points of the process selection and design of the sludge anaerobic digestion in wastewater treatment plant. Water Waste Eng. 39:41-44.

Chen, Y., Peng, C., Wang, J., Ye, L., Zhang, L., Peng, Y., 2011. Effect of nitrate recycling ratio on simultaneous biological nutrient removal in a novel anaerobic/anoxic/oxic (A2/O)biological aerated filter (BAF) system. Bioresour. Technol. 102:5722-5727.

Childers, D. L., Corman, J., Edwards, M., Elser, J. J., 2011. Sustainability Challenges of Phosphorus and Food: Solutions from Closing the Human Phosphorus Cycle. Bioscience 61:117-124.

Dai, W., Zhan, J., Mou, J., Liu, D., Liu, Y., 2008. The application of CWSBR process in Xiajiahe WWTP. Water Waste Eng. 34:38-41.

Dai, X., Zhao, Y., Sha, C., Dai, L., Dong, B., 2014. Investigation on the status and causes of sludge sand content of wastewater treatment plants in China. Water Waste Eng. 21.

De Ridder, M., De Jong, S., Polchar, J., Lingemann, S., 2012. Risks and opportunities in the global phosphate rock market: robust strategies in times of uncertainty. Hague Centre for Strategic Studies.

EC, 2014. 20 critical raw materials - major challenge for EU industry, 26 May 2014 ed. European Commission.

Egle, L., Rechberger, H., Zessner, M., 2015. Overview and description of technologies for recovering phosphorus from municipal wastewater. Resour. Conserv. Recycl. 105, Part B:325-346.

Fang, P., Cen, C., Tang, Z., Tang, Z., 2012. Air pollutants emission and their control from sludge incineration: A Review. Environ. Sci. Technol. 1.

FAO, 2009. Can technology deliver on the yield challenge to 2050?, How to Feed the World in 2050. Food and Agriculture Organization of the United Nations, Rome.

Fu, T., Chang, M., Zhong, L., 2008. Reform of China's Urban Water Sector. IWA Publishing, p. 26.

Garcia-Belinchón, C., Rieck, T., Bouchy, L., Galí, A., Rougé, P., Fàbregas, C., 2013. Struvite recovery: pilot-scale results and economic assessment of different scenarios. Water Pract Tech 8 .

GB4284-84, Control standards for pollutants in sludges from agricultural use. Ministry of Environmental Protection of the People's Republic of China, Beijing.

GB7478-87, Water quality- Determination of ammonium - Distillation and titration method. Ministry of Environmental Protection of the People's Republic of China, Beijing.

GB11893-89, Water quality-Determination of total phosphorus-Ammonium molybdate spectrophotometric method. Ministry of Environmental Protechtion of the People's Republic of China, Beijing.

GB18918-2002, Discharge standard of pollutants for municipal wastewater treatment plant. Ministry of Environmental Protection of the People's Republic of China, Beijing.

Gouider, M., Feki, M., Sayadi, S., 2009. Separative recovery with lime of phosphate and fluoride from an acidic effluent containing $\mathrm{H}_{3} \mathrm{PO}_{4}, \mathrm{HF}$ and/or $\mathrm{H}_{2} \mathrm{SiF}_{6}$. J. Hazard. Mater. 170:962-968.

Grzmil, B., Wronkowski, J., 2006. Removal of phosphates and fluorides from industrial wastewater. Desalination 189:261-268. 
Guo, G. i., Chen, T., Yang, J., Zheng, G., Gao, D., 2014. Regional distribution characteristics and variation of heavery metals in sewage sludge of China. Acta Scien. Circum. 34:24552461.

Guo, G. i., Yang, J., Chen, T. i., Zheng, G., Gao, D., Song, B., Du, W., 2009. Concentrations and variation of organic matter and nutrients in municipal sludge of China. China Water Wastewater 25:120-121.

Halling-Sørensen, B., Jorgensen, S. E., 1993. 2. Biological Nitrification and Denitrification, in: Halling-Sorensen B, Jorgensen S E (Eds.), Studies in Environmental Science. Elsevier, pp. 43-53.

Hao, X., Wang, C., Jin, W., 2011. Overview of phosphorus and phosphorus crisis recovery technology Global Change and Earth System Science Series. Higher Education Publishing: China.

Hao, X. D., Wang, C. C., Lan, L., van Loosdrecht, M. C. M., 2008. Struvite formation, analytical methods and effects of $\mathrm{pH}$ and $\mathrm{Ca}(2+)$. Water Sci. Technol. 58:1687-1692.

Heinzmann, B., Lengemann, A., 2014. Stand der Phosphorrückgewinnung in Berlin- Von wissenschaftlichen Untersuchungen zur großtechnischen Anwendung, Internationales Symposium "Re-Water Braunschweig", Braunschweig, Germany (in German).

HJ636-2012, Water quality-Determination of total nitrogen-Alkaline potassium persulfate digestion UV spectrophotometric method Ministry of Environmental Protechtion of the People's Republic of China, China.

Huang, L., Mao, X.-y., Wang, J., Chen, X., Wang, G.-h., Liao, Z.-w., 2014. The effect and mechanism of improved efficiency of physicochemical pro-release treatment for low grade phosphate rock. J. Soil Sci. Plant Nutr. 14:316-331.

Jiang, L., Yang, C., Hu, Q., Li, Z., Guo, Z., 2013. Operation analysis of sludge anaerobic digestion system at Bailonggang wastewater treatment plant. China Water Wastewater 29.

Jiang, Q., 2014. Recovery operation of sludge anaerobic digestion system at Gaobeidian WWTP. China Water Wastewater 30.

Jin, L., Zhang, G., Tian, H., 2014. Current state of sewage treatment in China. Water Res. 66:85-98.

Kabbe, C., 2015. P-REX Introduction: Hot spots for P recovery from municipal wastewater, Final International P-REX Workshop, Amsterdam.

Kabbe, C., Remy, C., 2013. Sustainable sewage sludge management fostering phosphorus recovery in Europe, 4. Internationale Symposium "Re-Water Braunschweig", Braunschweig.

Kataki, S., West, H., Clarke, M., Baruah, D. C., 2016. Phosphorus recovery as struvite: Recent concerns for use of seed, alternative $\mathrm{Mg}$ source, nitrogen conservation and fertilizer potential. Resour. Conserv. Recycl. 107:142-156.

Kong, X., 2012. The interpretation of policies on bioenergy from municipal waste in urban area, in: Center of Science and Technology of Construction M (Ed.).

Krüger, O., Adam, C., 2014. Monitoring von Klärschlammmonoverbrennungsaschen hinsichtlich ihrer Zusammensetzung zur Ermittlung ihrer Rohstoffrückgewinnungspotentiale und zur Erstellung von Referenzmaterial für die Überwachungsanalytik. Fachgebiet III 2.5 Überwachungsverfahren, Abwasserentsorgung, Dessau, Germany (in German).

Krüger, O., Adam, C., 2015. Recovery potential of German sewage sludge ash. Waste Manage. (Oxford) 45:400-406.

Li, H., Liu, J., Li, G., Shen, J., Bergström, L., Zhang, F., 2015. Past, present, and future use of phosphorus in Chinese agriculture and its influence on phosphorus losses. Ambio 44:274-285. Li, X., Li, G., Guo, S., Yan, B., 2007. Design and operation of sludge digestion in Wangxinzhuang Wastewater Treatment Plant in Zhengzhou. Water Waste Eng. 33:13-14.

Li, Y., Chen, T., Luo, W., Huang, Q., Wu, J., 2003. Contents of organic matter and major nutrients and the ecological effect related to land application of sewage sludge in China. Acta Ecologica Sinica 23:2464-2474. 
Lu, R., 2004. Phosphorus resource of China and phosphate fertilizer production and consumption Soils 36(1):1-4.

Manahan, S. E., 1997. Nitogen, Phosphorus, and Potassium in Soils, Environmental Science and Technology. Press LLC: United States of America, pp. 358-361.

MEP, 2014. List of national commissioning urban sewage treatment facilities in 2013. Ministry of Environmental Protection of the People's Republic of China (MEP) http://www.mep.gov.cn/gkml/hbb/bgg/201404/t20140415_270550.htm, p. (in Chinese). [Accessed by March 2016].

MEP, 2015. Notice of the State Council on Issuing the National Water Pollution Prevention and Treatment Action Plan of China Ministry of Environmental Protection of the Government of the People's Republic of China, Beijing (in Chinese).

MLR, 2012. Evolution of the Phosphate rock industry in Hunan. Ministry of Land and Resources of the People's Republic of China (MLR), http://www.mlr.gov.cn/kczygl/zhgl/201204/t20120411_1082843.htm, p. (in Chinese). [Accessed by March 2016].

MOHURD, 2016. China Urban-Rural Construction Statistical Yearbook 2013. Ministry of Housing and Urban-Rural Development http://www.mohurd.gov.cn/xytj/tjzljsxytjgb/index.html (in Chinese). [Accessed by March 2016].

NCME, 2013. Environmental Impact Assessment of Jinnan sludge treatment. North China Municipal Engineering Design \& Research Institut, Tianjing, p. 40.

Ndala, S. m., Claassens, A., Makaringe, P., Dube, B., 2010. Citro-Acidulation of Rock Phosphates for Rapid Conversation of Fluorapatite to Hydroxyapatite, in: Zhang P, Swager K, Filho L L, El-Shall H (Eds.), Beneficiation of Phosphates: Technology Advance and Adoption. Society for Ming, Metallurgy \& Exploration: USA, pp. 197-203.

Niewersch, C., Stemann, J., Ewert, W., Hermanussen, O., Kabbe, C., Mêlè, C., Paillard, H., Stössel, E., 2014. Description of sludge related processes, Sustainable sewage sludge management fostering phosphorus recovery and energy efficiency, P-REX Deliverable D5.1, 29 April 2014 ed, http://p-rex.eu/index.php?id=11.

Pan, B., Lu, Z., Sun, C., 2006. Operational Analysis of Sludge Digestion in Wastewater Treatment Plant in Haikou City. China Water Wastewater 22:91-94.

Peng, Z., Peng, Y., Gui, L., Liu, X., 2010. Competition for Single Carbon Source Between Denitrification and Phosphorus Release in Sludge under Anoxic Condition. Chin. J. Chem. Eng. 18:472-477.

Petzet, S., Cornel, P., 2009. P-recovery from sewage sludge and sewage sludge ashes. Presentation in BALTIC 21.

Qiu, G., Ting, Y.-P., 2014. Direct phosphorus recovery from municipal wastewater via osmotic membrane bioreactor (OMBR) for wastewater treatment. Bioresour. Technol. 170:221-229.

Qiu, S., Ding, T., 2002. Explore the biological treatment of urban sewage effluent total phosphorus compliance issues China Water and Wastewater 18:23-25.

Remy, C., 2015. Deliverable D 9.2 Life Cycle Assessment of selected processes for P recovery from sewage sludge, sludge liquor, or ash, Sustainable sewage sludge management fostering phosphorus recovery and energy efficiency (P-REX), http://prex.eu/index.php?id=11.

Römer, W., 2013. Phosphor-Düngewirkung von P-Recyclingprodukten. Korrespondenz Abwasser, Abfall 60:202-215 (in German).

Sun, C., Shi, Z., Shen, Z., 2008. Analysis of sludge disposal techniques in municipal sewage plants of Hainan. Journal of Hainan normal university (natural science) 21:303-306.

USGS, 2015. PHOSPHATE ROCK: World Mine Production and Reserves, Mineral Commodity Summaries, America. 
Wang, F., Li, H., Chen, X., 2012. Mesophilic Sludge Digestion and Heat and Power Cogeneration in Qingdao Maidao WWTP. China Water Wastewater 28:49-51.

Wang, X., Zhao, B., Zhang, A., Sha, Z., 2015. The Present Situation and Research Progress of Treatment of Sludge from City Sewage Treatment Plant. Tianjin Daxue Xuebao 30.

WB, 2014. World Development Indicators: Rural environment and land use. The World Bank. Wei, B., Yang, L., 2010. A review of heavy metal contaminations in urban soils, urban road dusts and agricultural soils from China. Microchem. J. 94:99-107.

Wiechmann, B., Dienemann, C., Kabbe, C., Brandt, S., Vogel, I., Roskosch, A., 2015. Sewage sludge management in Germany, Bonn.

Wilken, V., Zapka, O., Muskolus, A., 2015. Product quality: fertilizing efficiency, results of pot and field tests, Final International Workshop Proceedings - P-REX Consortium, Amsterdam.

Yang, G., Zhang, G., Wang, H., 2015. Current state of sludge production, management, treatment and disposal in China. Water Res. 78:60-73.

Zhang, F., Zhang, W., Ma, W., 2009. China's Phosphorus (P) Fertilizer Industry: Development and Outlook, The Chemical Fertilizer Industry in China: A Review and its Outlook International Fertilizer Industry Association.

Zhang, W., Qi, D., Wu, S., Dong, J., Zhao, W., 2014. Effect of Different Pretreatment Methods on Sewage Sludge Anaerobic Digestion. Transactions of the Chinese Society for Agricultural Machinery 45:187-198.

Zhang, X., 2009. The run and praetice of sludge anaerobic digestion treatment for the sewage treatment plant of Jiguanshi. Automat Instrum:115-119.

Zhu, Y., 2009. Design of the sludge digestion system of Sanjintan Wastewater Treatment Plant in Wuhan City. Water Waste Eng. 35:40-43. 